\title{
営業部門での管理方式の選択に関する一考察 一多角的な視点加分析した営業管理様式の選択要因について
}

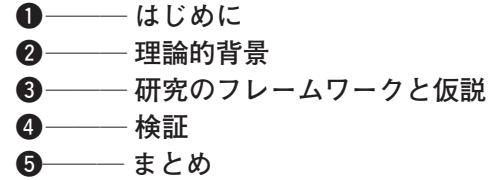

\section{金 顕哲}

ソウル大学国際大学院 準教授

\section{清宮 政宏}

富士ゼロックス株式会社

\section{1—はじめに}

本研究は，営業部門の管理が，どのような 理由で選択されるかについて，分析を進めた 実証研究である。

営業部門の管理は，成果とは因果関係の分 析が指向されながらも，それが選択される理 由については，「成果を正しく評価する能力」 と「達成までのプロセスの明白性」という二 要因が引用され，先行研究では分析がなされ るばかりである。しかし，本来は分析される 必要のある，営業部門の戦略や行動，タスク や環境等の与件によって，それをどのように 変更すべきかについては分析されてきていな いのが実状である。本研究では，営業部門の 管理方式選択のあり方について，これらとの 因果関係に焦点をあて分析を試みた。

その結果，標準的な戦略や行動が指向され る場合には，アウトプット管理等が用いられ， また顧客適応的な戦略や行動が指向される場
合には，プロセス管理等が用いられることが 確認された。そして，タスク複雑性や環境不 確実性が増す場合にも，プロセス管理等が用 いられ，さらに，機動的な顧客カバーや提案 型営業，新規顧客開拓などの積極的な営業活 動が展開される場合には，営業管理がその種 類を問わず，全般的に用いられることも確認 された。

このような結果から示唆として得られたこ とは，営業管理の選択は，実務においても研 究においても，多角的な側面から分析され設 計される必要があることであり，実務での経 験中心による管理方法決定や，研究での成果 主義的（成果主義ベース管理，アウトプット 管理等）か，行動主義的（行動主義ベース管 理，プロセス管理等）かという二元対比での 分析には限界があるということであった。

\section{2 理論的背景}

\section{1. 営業管理様式研究の流れ}

営業部門の管理（営業管理様式）に関する 研究は，実務では一般的である成果主義的な 管理に対し，行動主義的な管理の有効性を唱 えることにより進められてきている。 
この営業管理様式に関する研究は, Anderson \& Oliver（1987）が起点と考えられている。 Anderson \& Oliver（1987）は，それ以前の 研究を整理し, Commission（手数料報酬）に もとづく成果主義ベース管理よりも，Salary （固定給）にもとづく行動主義ベース管理が, 営業員の知識や販売技術, 動機付けの向上で, 優位性の高いものであるとし，二つの管理方式 の違いや, 行動主義ベース管理の優位点を $7 つ$ の命題にまとめている。

これに続くのがCravens et al. (1993), Oliver \& Anderson (1994), Challagalla et al.（1997）であるが, Cravens et al. (1993) では、Anderson \& Oliver（1987）の命題の一 つである「目標指向性」に焦点をあてたモデ ル構築を行い, 行動主義ベース管理が用いら れることによって，営業部門の目標指向性が 高まり，結果として営業部門の業績も高まる ことを実証している。

またOliver \& Anderson（1994）は，営業 管理様式と営業員の内的効果に対する集中的 な分析を行い，行動主義ベース管理が用いら れる場合には，営業員の態度形成や動機づけ の向上，行動の計画化がはかられ，その専門 能力の向上がはかられることを実証している。

そして, Challagalla et al. (1997) は, 行動 主義べース管理の概念が漠然的であることを 指摘し，それを解消させるために，行動主義 ベース管理を，行動内容（activity）をベース にした管理と，行動能力（capability）をべー スにした管理の二つに分け，成果 (Output) を含めた三つの管理方式と，あわせて提示し た情報フィードバック (Information)，報酬 (Reward)，罰則（Punishment）という展開
方法が，有意であることを確認している。

さらに, Jaworski (1988), Jaworski et al. （1993）は，選択要因と，管理方式，成果とい う三段階の分析フレームを構築して分析を行 ない, また, 高嶋（2000a，2000b）も，営業 管理様式研究を日本企業の営業部門に適用さ せて，その因果関係について，分析を行って いる。そして清宮（2004a）では，成果主義的 な管理と行動主義的な管理は，寄与する成果 が異なり，成果主義的な管理は売上・利益に 寄与するのに対し，行動主義的な管理は営業 員の内的効果や顧客満足度向上に寄与すると して分析を進めている。

このように営業部門の管理は，成果主義的 か, 行動主義的かという象徵的な対比や, 成 果との因果関係には焦点があてられながらも, その管理が何故選択されているのか，また前 提となる与件が変化した場合に，それがどう 変更されるべきかについては，極めて単純な 二要因が引用されて論述が展開されているば かりで，実務に対して，有意義な選択のため の分析フレームの提示ができていないのが実 状である。結果として, 営業研究全般でも, 「実務」への意義ある示唆の提示ができない理 由の一つとなっているといえよう。

\section{2. 既存研究の中での営業管理様式の選択要因}

実務での営業部門の管理は，その組織での 様々な経験蓄積を背景に選択が行なわれてい ると考えて異論はないであろう。しかし，理 論を導出しずらそうに見える実務の経験則の 中にも何らかの法則性があるのでないかと考 えられる。

これについて研究では, 営業部門で成果主 
口図-1

W. Ouchi （1979）での管理方式の選択の概念図

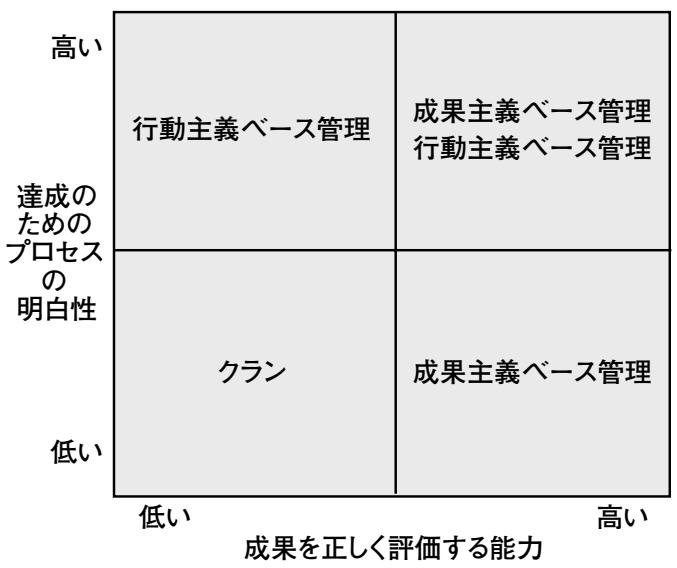

義的な管理と，行動主義的な管理のどちらが 選択されるかについて，冒頭に上げた，W． Ouchi（1979）の「成果を正しく評価する能 力」と「達成までのプロセスの明白性」とい う二要因が引用されて，基本的に分析がなさ れている。

W. Ouchi（1979）は，図ー1にあるように 「成果を正しく評価する能力」が高い場合には, 成果主義べース管理が用いられ，「達成のため のプロセスの明白性」が高い場合には行動主 義ベース管理が用いられるとし，どちらも低 い時には，クラン（組織で共有される価值観 にそった管理）が行なわれるとしている。

しかし, Anderson \& Oliver (1987) 以来, 営業管理様式の選択を決定するものとして引 用されるこの W. Ouchi（1979）の二要因は, もともとは営業部門の管理を想定してつくら れたものでなく，工場や事務部門などの，本 質的に性質の異なる管理を比較するために作 成されたものである。つまり，売上・利益の 獲得を目指すという点では同質的ながらも,
企業が市場戦略を具現化する中で期待役割が 変化し，外部環境の変化を最も受ける営業部 門の管理を，より動態的に分析しようとする にはやや難があるものといえる。

上述の二要因を引用して分析を行なった Anderson \& Oliver（1987）に続き，管理方 式の選択要因について研究を進めているのが, Eisenhardt (1985), Jaworski (1988), Jaworski et al. (1993)，高嶋（2000a）である。

Eisenhardt（1985）は，営業管理様式の選 択を分析する視点として，W. Ouchi（1979） による組織分析的な視点以外に，エージェン シー理論，取引コスト分析，認知的評価論の 3つの分析視点があるとし，その中でエージ エンシー理論をもとに，「評価尺度を使うため のコスト」と「販売における不確実性」で営 業管理様式の選択に関する分析を行っている ${ }^{1)}$ 。

また, Jaworski (1988), Jaworski et al. （1993）は，環境要因や先行要因によって，管 理方式が決定されるとし，分析モデルを構築 して分析を行っている2)。

そして，高嶋（2000a）は，Anderson \& Oliver（1987）の研究を引用しながら, 基本 的にはW. Ouchi（1979）のフレームを使って， 日本企業に扮ける特徵を分析している。なお， 高嶋（2000a）が使用した調査データでは，顧 客ニーズが異質で（プロセス知識が低くなる 場合で)，業績評価が複雑な状況の場合（成果 を判断する能力が低くなる場合）には，クラ ンでなく，アウトプット管理の比率が高くな っていたとしている。高嶋（2000b）はこれ について，クラン的な管理（組織で共有され る価值観にもとづく管理）として，日本企業 では，アウトプット管理が行なわれているか 
らであろうと推論している。

\section{3. 先行研究での課題}

このような営業管理様式研究は, その流れ をみると, 米国で蓄積されてきた人的販売研 究や販売管理論を発展させたものと考えるこ とができる。しかし，その選択のあり方につ いて，より多角的に分析するには，人的販売 研究や販売管理論では見逃されがちな, 営業 活動での資源配分のあり方（営業戦略）や, 顧客への対処の仕方（営業行動）にも留意し ながら，分析を行なう必要があるといえる。

しかし先行研究で，何故，W. Ouchi（1979） の二要因が引用されて分析されてきたかとい えば, その理由の一つは, この営業管理様式 研究が, 米国で蓄積されてきた人的販売研究 や販売管理論を発展させたものであるため, その分析アプローチの構造的な限界を引き継 いているからだと考えられるのである。

なぜなら人的販売研究・販売管理論研究は, 営業部門内で操作や変更が可能なものを分析 対象とし, 科学的な手法でそれらの課題解決 を目指すものである。そのため，その企業が 目指す資源配分や, 顧客との関係を, その分 析に織り达むことはそれほど目指されていな い。

しかし，企業で実際に行なわれる営業管理 は，資源配分のあり方や，顧客への対処とい う点から影響を受けて, 選択がなされている はずである。

よって，管理方式選択のあり方をより多角 的に分析するには, 既存の研究を参考にしな がらも, 営業戦略や営業行動という視点も折 り达んで, 分析を行う必要があると考えられ
るのである。

\section{3 研究のフレームワークと仮説}

\section{1. 研究のフレームワーク}

日本企業の資源配分 (戦略) について, 石 井（1993）は，経営資源の不可逆性があり, 戦略目標達成のために新たな資源を集めるの でなく，既存資源をどのように活用するか， という点で戦略が採用される傾向があるとし ている。つまり，営業部門の管理も，このよ うな資源配分に関する指向性（営業戦略）と 因果関係を持ちながら，選択がなされている はずである。

また，顧客との関係についても，特に米国 と日本の違いとして, 米国では常に新たな取 引相手を模索し代替的な取引相手を念頭に置 きながら行動するのに対して, 日本では商取 引が固定的（細井，2000）で，特に売手にと っては, 顧客との関係をいかに保つか, 取引 を深めて行くかという点に目標が置かれてい ることがあげられる。このような売手の買手 への対処 (営業行動) という点とも因果関係 を持ちながら，営業管理様式の選択がなされ ているはずである。

さらに営業管理は, そのタスクの性質によ っても, 選択されるものが異なるはずである。 営業タスクが新規開拓であるか既存顧客維持 であるか（田中，1986），また取引ごとのサイ クルが長いか短いか (Jaworski et. al., 1993), そしてタスクの複雑性（Jaworski et. al., 1993; 高嶋 2000b）の高さ等によっても，選択され る管理方式が異なると考えられる。また, 競 争状況の変化や, 市場の変化等の環境変化に よっても, 選択のあり方が変化するであろう。 
口図—2

営業管理様式の選択との因果関係について分析や 考察を行うべき視点

一営業戦略・営業行動・タスク特性・環境特性一

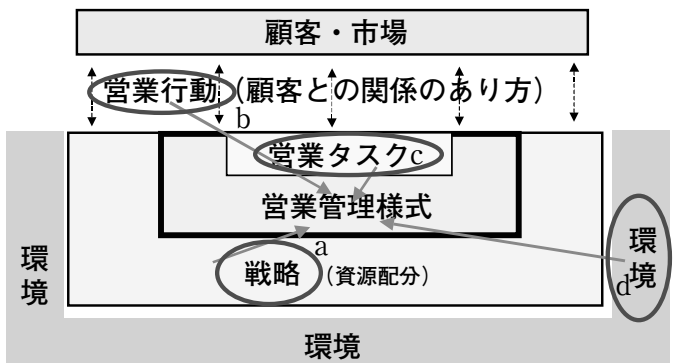

图-3

営業の業務プロセスと 4 つの管理方式

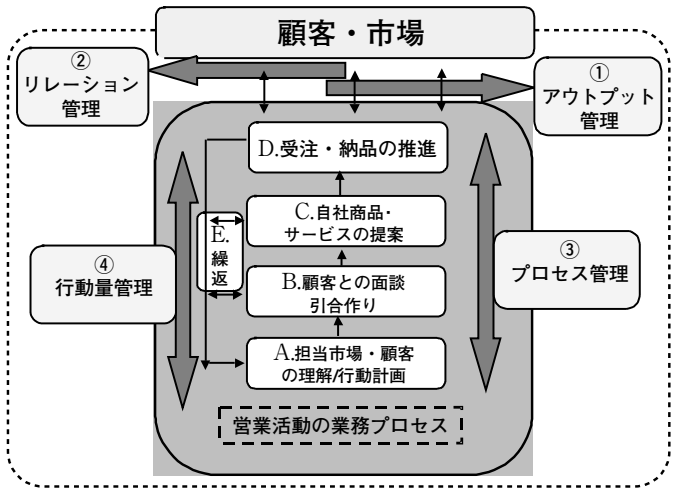

\section{(図一 2 参照)}

営業管理の選択に至る様相を，より具体的 に分析するために，本研究では，営業の業務 プロセスのどの部分を重視するかにあわせて （清宮 2004b），営業管理を，アウトプット管 理，リレーション管理，プロセス管理，行動 量管理の 4 つに分け (図一 3 参照 $)^{3)}$, 前節で 取り上げた営業戦略, 営業行動, 夕スク特性, 環境特性という4つの要因と，選択との因果 関係について，分析を進めることにした (図一 4 参照)。

\section{2. 研究仮説の設定}

以上のフレームにそって，以下の仮説を設 定した。

（1）営業戦略/営業行動と営業管理様式の選択 営業戦略や営業行動はその性質によって, 標準的（高嶋,1998）なものと, 顧客適応的 （高嶋,1998）なものとに分けることができる。 標準的な戦略·行動が指向される場合は，一律 的に行なえるアウトプット管理や行動量管理

図- 4

営業管理様式の選択に関する分析フレーム

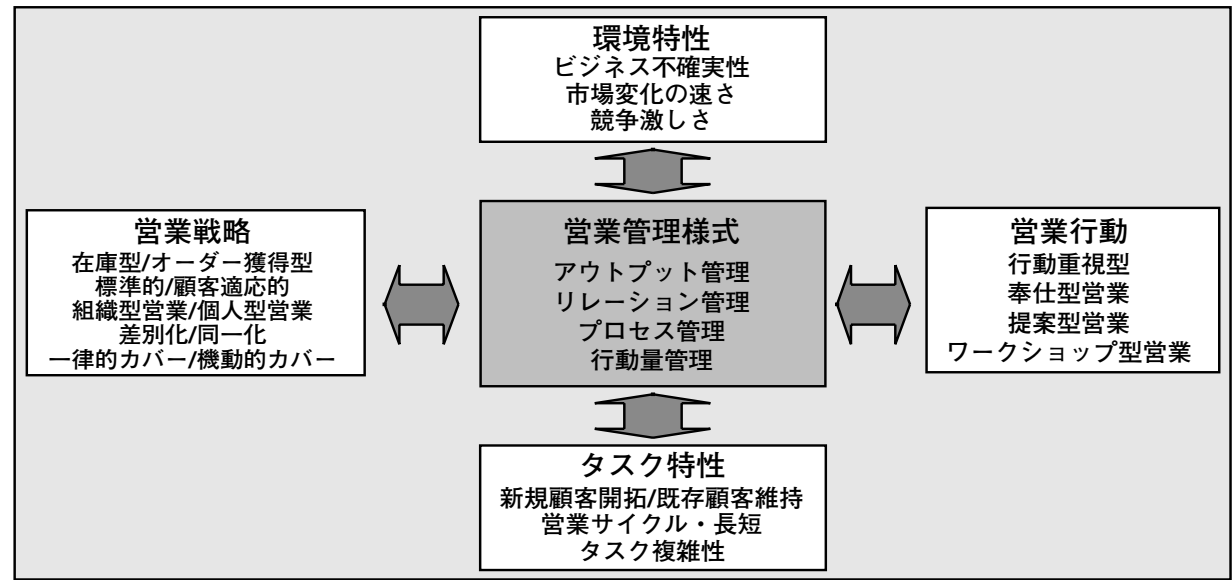


の遂行度が高まり, 顧客適応的な戦略・行動が 指向される場合には, 顧客との関係で変更が 伴うプロセス管理やリレーション管理の遂行 度が高まるであろう。このような営業戦略・ 営業行動の性質の違いによって選択される営 業管理も差異が現れると考え，仮説を設定し た。

\section{1 ) 在庫形成と製品·サービスの提供のあり方} (在庫型営業/オーダー獲得型営業)

在庫をもった型で行われる投機的 (Bucklin, 1965; 石井, 1998; 金, 1995）な営業では，製 品・サービスの仕様・数量はあらかじめ決定さ れるため, 目標值は明確で業務プロセスの詳細 な管理も不要である。そのため, 管理は, 一律 的なアウトプット管理や行動量管理が用いられ ると考えられる。

またオーダー獲得を中心とした型の延期的 (Alderson,1956; 石井,1998; 金, 1995）な営業で は，製品・サービスの仕様・数量が買手の意向 や動向にゆだねられており，それを確実に製 品・サービスの仕様・数量に反映させる必要が ある。よって，営業プロセスの詳細な管理が 行なわれ，それを重視するプロセス管理が用 いられると考えられる。

仮説 $1-1$. 在庫型営業が指向される場合に は, アウトプット管理, 行動量 管理の実践度が高まる。

仮説 1 - 2. オーダー獲得型営業が指向され る場合には，プロセス管理の実 践度が高まる。

\section{2 ) 製品·サービスの性質 (標準的/顧客適応的)} 標準的（高嶋, 1998）な製品・サービスを扱
う場合は，標準化された製品・サービスを確 実に販売することが求められる。営業目標や 営業員の期待役割が明確であるため，一律的 に行なえるアウトプット管理や，活動量が重 視される行動量管理が用いられるはずである。

また，顧客適応的（高嶋，1998）な製品・サ ービスを扱う場合は，製品・サービスの仕様 や数量を，買手の意向に的確に適合させる必 要がある。そのため, ビジネスプロセスの共 有や仕様決定の協働を重視するプロセス管理 が用いられると考えられる。

仮説 2-1. 標準的な製品·サービスの扱いを 指向する場合には，アウトプッ 卜管理, 行動量管理の実践度が 高まる。

仮説 $2-2$. 顧客適応的な製品・サービスの扱 いを指向する場合には、プロセ ス管理の実践度が高まる。

\section{3 ）営業活動における意思決定段階と責任の 所在のあり方}

組織型営業（高嶋, 1995）を指向する場合は, 組織連携の中で活動の整合性が求められる。 そのため，業務プロセスの共有を重視するプ ロセス管理が用いられると考えられる。

逆に個人型営業（高嶋, 1995）が指向される 場合は，営業員が個別に成果を追求し，最終 的な売上・利益·販売数を中心に管理が行われ るようになる。そのため，管理も一律的なア ウトプット管理が用いられると考えられる。

仮説 3-1. 組織型営業が指向される場合に は，プロセス管理の実践度が高 まる。 
仮説 3-2. 個人型営業が指向される場合に は，アウトプット管理の実践度 が高まる。

\section{4 ) 市場への対応 1 (差別化·同一化の方向性)}

差別化戦略（Porter；1985, 嶋口；1986) は，買手のニーズと売手の持つシーズとを適 合させながら，競争相手（品）との差違を明 確に訴求しようとするものである。そのため, 顧客・市場には個別的な対応が必要で，プロセ ス共有が重視されるプロセス管理が用いられ るはずである。

逆に，同一化戦略 (嶋口；1986, Slater;2000) を指向する場合は，均一的な性質の市場対応が なされる。そのため，細かな営業プロセスは管 理されず，最終的な成果が重視されるアウトプ ット管理が用いられると考えられる。

仮説 4-1. 差別化戦略を指向する場合には, プロセス管理の実践度が高まる。

仮説 4-2. 同一化戦略を指向する場合には, アウトプット管理の実践度が高 まる。

\section{5 ）市場への対応 2 (顧客·市場カバーのあり方)}

一律的な顧客・市場カバーを指向する場合 は，全方位的なカバーが目指される。そのた め, 標準的·均一的な市場対応が行なわれ，管 理は，一律的に行なわれるアウトプット管理 や，幅広い顧客・市場カバーを目指す行動量管 理が用いられると考えられる。

逆に，機動的な顧客・市場カバー（田村, 1999）を指向する場合は，顧客・市場を細分 化し，きめ細かな顧客適応的な対応を行なう 必要がある。よって，ビジネスプロセスの共
有が重視されるプロセス管理が用いられると 考えられる。

仮説 $5-1$. 一律的な市場カバーを指向する 場合には，アウトプット管理， 行動量管理の実践度が高まる。

仮説 5-2. 機動的な市場カバーを指向する 場合には，プロセス管理の実践 度が高まる。

\section{6 ) 行動重視型営業}

行動重視型営業（嶋口，1995；1997）は，売 手・買手ともに本質的ニーズの解決方法が既 知である場合にとられる営業行動である。目 標は明確で均一的な行動であるため，営業管 理は，管理指標が明確なアウトプット管理や， 活動量が重視される行動量管理が用いられる と考えられる。

仮説 6 . 行動重視型営業が指向される場合に は，アウトプット管理と行動量管理 の実践度が高まる。

\section{7 ) 適応奉仕型営業}

適応奉仕型営業（嶋口，1995；1997）は，買 手は本質的ニーズの解決方法を既知ながら， 売手は未知である状態で採られる営業行動で ある。売手は，常に顧客の要求にあわせて対 処するため，顧客適応的な行動といえる。そ のため，顧客との関係強化や，ビジネスプロ セスの共有を重視する, リレーション管理, プロセス管理が用いられると考えられる。

仮説 7 . 適応奉仕型営業が指向される場合に は, リレーション管理, プロセス管 
理の実践度が高まる。

\section{8 ) 提案型営業}

提案型営業（嶋口，1995；1997）は，売手に とっては本質的ニーズの解決方法を既知なが ら, 買手は未知の状態で採られる営業行動で ある。売手の比較的自由な目標設定のもとで, 積極的・一律的な行動が行なわれるため，標 準的な性質の営業行動といえる。よって，ア ウトプット管理や，行動量管理が用いられる 可能性がある。しかし, 顧客 (買手) が未知 の本質的ニーズを顕在化させるため, 顧客と の関係を重視するリレーション管理や, 顧客 への提案内容を営業プロセスで共有する，プ ロセス管理も用いられる可能性がある。この ようなことから提案型営業と 4 つの管理方式 の因果関係を確認するため, 以下の仮説を設 定することにする。

仮説 8 . 提案型営業が指向される場合には, アウトプット管理, リレーション管 理, プロセス管理, 行動量管理,の 実践度が高まる。

\section{9 ) ワークショップ型営業}

ワークショップ型営業（嶋口，1995; 1997） は，売手も買手も本質的ニーズの解決方法が 未知の状態で採られる営業行動である。売手 と買手が互いに本質的ニーズの解決方法を探 索しょうとニーズやシーズを持ち寄りながら， 取引が進められるものである。つまり，顧客 適応的な性質の営業行動といえる。売手と買 手が持ち寄るニーズやシーズの適合性や実現 性が確認されながら営業行動が行われるため, 管理は，ビジネスプロセスの共有を重視する
プロセス管理が用いられるはずである。

仮説 9. ワークショップ型営業が指向される 場合には，プロセス管理の実践度が 高まる。

\section{（2）タスク特性/環境特性と営業管理様式の選択}

夕スク特性や環境特性によっても営業管理 選択との因果関係が見出されるはずである。 タスクの複雑性が増す場合や環境不確実性が 増す場合には，リスク軽減のために組織的な 営業プロセスの共有を目指すプロセス管理等 が用いられ，また，顧客との良好な関係構築 が必要とされる場合にはそれを重視するリレ ーション管理が用いられるであろうと考え, 仮説を設定した。

\section{1 ）新規顧客開拓/既存顧客維持}

新規顧客開拓（田中, 1986）は，取引のない 顧客との取引の開始を目指すものである。新 たな売上・利益の獲得を目指して, 営業部門で は積極的で自由な目標設定が行われ，標準的 な営業活動が行なわれるはずである。よって 管理も，一律的に行なえるアウトプット管理 や，顧客の幅広いカバーを目指す行動量管理 が用いられると考えられる。

また既存顧客維持（田中, 1986）では，特定 顧客との取引関係の維持や拡大が目指される。 そのため, 顧客適応的な活動が行なわれ, 顧 客との関係を重視するリレーション管理が用 いられると考えられる。

このような営業タスクの特性（新規顧客開 拓/既存顧客維持) によって, 用いられる管理 方式が異なるであろうことを検証するため, 以下の仮説を設定する。 
仮説 10-1. 営業タスクが新規顧客開拓の 場合には，アウトプット管理, 行動量管理の実践度が高まる。

仮説 $10-2$. 営業タスクが既存顧客維持の 場合には,リレーション管理 の実践度が高まる。

\section{2 ) 営業サイクルの長さ}

営業サイクルが長い（Jaworski et. al., 1993） 場合は，特定顧客に対応する活動時間が長く なり，活動がその顧客に対して顧客適応的・ 個別的になるはずである。よって，顧客との 関係が重視されるリレーション管理や，プロ セス共有が重視されるプロセス管理が用いら れると考えられる。

逆に，営業サイクルが短い（Jaworski et. al., 1993）場合は，小さな取引を次々と完結さ せる必要があり，個々の顧客との取引には慎 重にならず，活動が標準的になるはずである。 よって管理も，一律的に行なわれるアウトプ ット管理が用いられると考えられる。

このような営業タスクの特性（営業サイク ル長/短) によって，用いられる管理方式が異 なるであろうことを検証するため，以下の仮 説を設定する。

仮説 11-1. 営業サイクルが長い場合には, リレーション管理, プロセス 管理の実践度が高まる。

仮説 $11-2$. 営業サイクルが短い場合には, アウトプット管理の実践度が 高まる。

\section{3）タスク複雑性}

営業タスクの複雑性（Jaworski et. al., 1993; 高嶋, 2000b）が高い場合は，取引状況や進度 を見極めながら，活動を個々に管理する必要 がある。そのため，プロセス共有や進渉状況 把握を重視するプロセス管理が用いられると 考えられる。

仮説 12. 営業タスクの複雑性が高い場合には, プロセス管理の実践度が高まる。

\section{4 ）ビジネス不確実性}

ビジネスの不確実性（Jaworski, 1988）の高 い環境下では，不確定な要素を取り除こうと するために，状況確認や活動の適合性の確認 を頻繁に行なう必要がある。そのため，プロ セス共有や進渉状況把握を重視する，プロセ 又管理が用いられると考えられる。

仮説 13. ビジネスの不確実性が高い場合には, プロセス管理の実践度が高まる。

\section{5 ）市場変化の速さ}

市場変化が速い（Jaworski, 1988）中では, 顧客や競争他社の動向の変化にあわせて，的 確に適応していく必要がある。そのため，プ ロセス共有や進渉状況を重視するプロセス管 理が用いられると考えられる。

仮説 14. 市場変化が速い場合には，プロセス 管理の実践度が高まる。

\section{6 ）競争の激しさ}

競争の激しい（Jaworski, 1988）環境下では, 競争他社に打ち勝つため, 状況に応じた適確 な営業活動を展開する必要がある。そのため, 
顧客との良好な関係や，プロセス共有や進渉 状況把握を重視する,リレーション管理，プ ロセス管理が用いられると考えられる。

仮説 15. 競争が激しい場合には, リレーショ ン管理，プロセス管理の実践度が高 まる。

\section{(4) 検証}

\section{1. 検証方法}

検証のためのデータは, 2002 年 $2 \sim 3$ 月に 行われた，「営業活動と営業管理に関する調査 アンケート」という調查で得られたデータを 使用した。このデー夕をもとに, 営業戦略, 営業行動, 夕スク特性, 環境特性と, 管理方 式の選択との因果関係についての測定を行っ た。調查項目は, 表一 1 に示したとおりで, 回答は自社にあてはまるものを 7 段階の中か ら選んでもらう選択方式とした ${ }^{4}$ 。

検証にあたっては, 今回の研究で分析フレ ームに組み达んだ営業戦略, 営業行動, タス ク特性, 環境特性と, アウトプット管理, リ レーション管理, プロセス管理, 行動量管理 という 4 つの管理方式に関して，図ー5に示 したような統合的な共分散構造分析モデルを 構築し, 営業戦略, 営業行動, 夕スク特性, 環境特性のそれぞれから，管理方式へのそれ ぞれのパスの標準化係数の高さ，および有意 性について確認し，検証を行なった。

\section{2. 検証結果}

検証結果は表一 2 である。有意水準は, 片 側 $5 \%$ （両側 $10 \%$ ）とした。表一2にある通
り, 営業戦略, 営業行動, 夕スク特性, 環境 特性から営業管理様式へのパスには，1\%水 準で有意なもの，5\%水準で有意なもの，ま た $5 \%$ 水準で有意でないものが混在している。 しかし，5\%水準で有意でないものにも，符 号（正・負）条件によって，その因果関係が 推論できるものがある。

\section{（1）営業戦略/営業行動と営業管理様式の選択}

仮説 1 の検証結果は, 表-2 の(1)で, 仮説 $1-1$ （在庫型 $\rightarrow$ アウトプット管理, 行動量 管理), 仮説 $1-2$ (オーダー獲得型 $\rightarrow$ プロセ ス管理）とも，支持されなかった。

仮説 2 の検証結果は(2)である。仮説 $2-1$

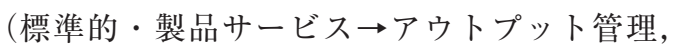
行動量管理）では，アウトプット管理だけが 支持された。他方，仮説 $2-2$ (顧客適応 的・製品サービス $\rightarrow$ プロセス管理）は支持さ れた。しかし，仮説 $2-2$ (顧客適応的・製 品サービス）では，アウトプット管理との正 の因果関係も認められ，全体としての仮説 2 での，標準的/顧客適応的・製品サービスとい う対比で，管理方式選択が異なるということ は確認できなかった。

仮説 3 の検証結果は(3)である。仮説 $3-1$

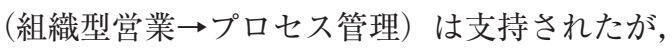
仮説 $3-2$ (個人型営業 $\rightarrow$ アトプット管理) は支持されなかった。なお，仮説に含めなか ったこととして, 個人型営業では行動量管理 が選択され，プロセス管理とは負の因果関係 が確認できるものとなっている。

仮説 4 の検証結果は(4)である。仮説 4-2 
表— 1

営業戦略、営業行動、タスク特性、環境特性と営業管理様式の調査項目

\begin{tabular}{|c|c|}
\hline 業戦略、営業行動、夕ス万特性、環境特性 & 質問項目 \\
\hline 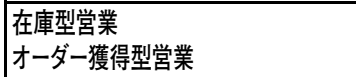 & $\begin{array}{l}\text { 貴社の製品は、顧客からの需要を見込んで、ある程度在庫されている。 } \\
\text { 貴社の製品・サービスは、顧客からのオーダーに塘たた後に、作成·提供されるものである。 }\end{array}$ \\
\hline 栖準的製品·サービス & $\begin{array}{l}\text { 貴社の製品·サービスは、全ての顧客に対し、均一的なものである。 } \\
\text { 貴社の製品・サービスは、顧客の要求·要望により、その内容を大き〈変えるものである。 }\end{array}$ \\
\hline $\begin{array}{l}\text { 営業活動での責任の所在(組織型営業) } \\
\text { 業活動での責任の所在(個人型営業) }\end{array}$ & $\begin{array}{l}\text { 貴社の営業活動では、顧客との取引に関する決定や責任は、部門として連带的に行い責任を負っている。 } \\
\text { 貴社の営業活動では、顧客との取引に関する決定や責任は、営業員が個々に負っている。 }\end{array}$ \\
\hline $\begin{array}{l}\text { 競争との差別化志向の強さ } \\
\text { 競争との同一化志向の強さ }\end{array}$ & $\begin{array}{l}\text { 貴社の営業活動は、市場の中で強力な就争他社と自社の差別化をいながら、行なわれている。 } \\
\text { 貴社の営業活動は、自社の狚う顧客とはほほほ取引き可能であるとい、市場を有望視する中で行なわれている。 }\end{array}$ \\
\hline $\begin{array}{l}\text { 一律的な顧客·市場のカバー } \\
\text { 機動的な顧客·市場のカバー }\end{array}$ & 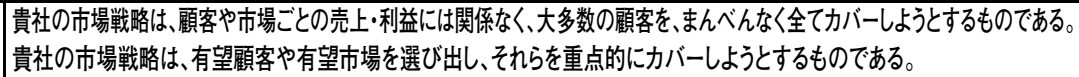 \\
\hline $\begin{array}{l}\text { 行動重視型営業 } \\
\text { 適応奉仕型営業 } \\
\text { 提案型営業 } \\
\text { ワークショシフ型営業 }\end{array}$ & 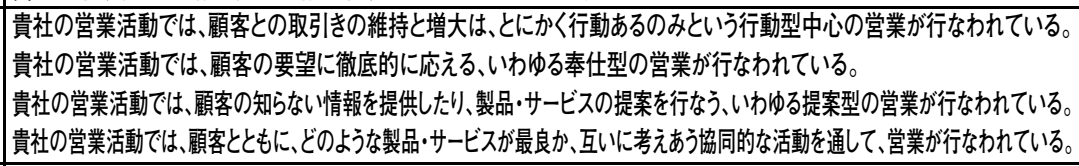 \\
\hline $\begin{array}{l}\text { 新規開拓 } \\
\text { 短·存顧営客維持 } \\
\text { 業サイルル } \\
\text { タスク複雑性 }\end{array}$ & 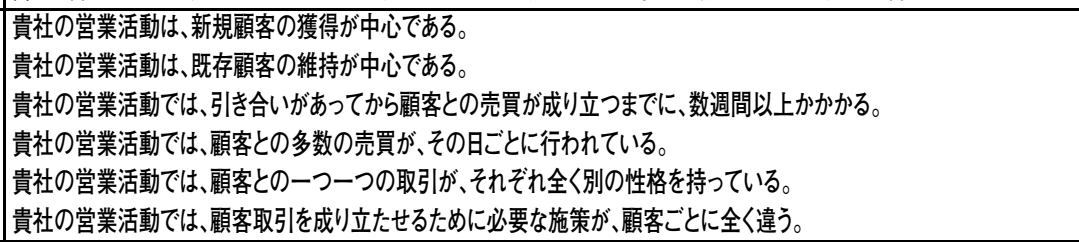 \\
\hline 市不堆実性 & 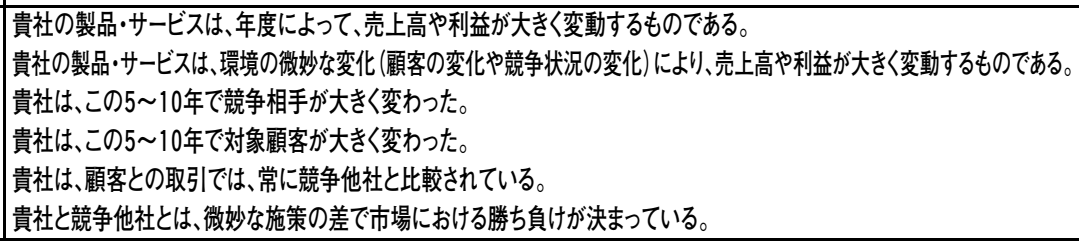 \\
\hline
\end{tabular}

\begin{tabular}{|c|c|}
\hline 営業管理様式 & 質問項目 \\
\hline $\begin{array}{l}\text { アウトプット管理 } \\
\text { (アウトプット管理-売上高) } \\
\text { (アウトプッ管理-利益高) } \\
\text { (アウトプット管理-販売単位数) }\end{array}$ & 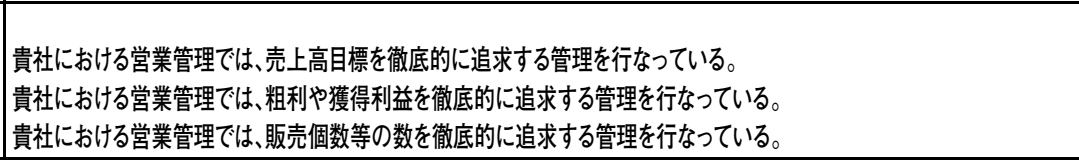 \\
\hline $\begin{array}{l}\text { リレーション管理 } \\
\text { (リレーション管理-人間関係強化) } \\
\text { (リレーショシ管理-取引関係改善) } \\
\text { (リレーション管理-既存取引の維持緭続) }\end{array}$ & 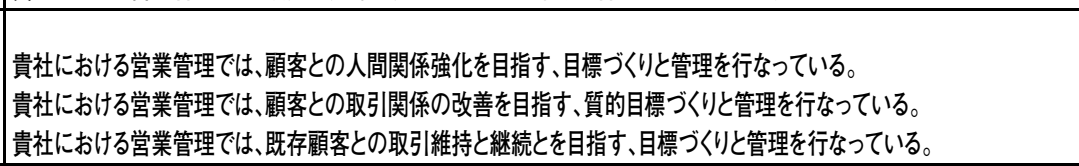 \\
\hline $\begin{array}{l}\text { プロセス管理 } \\
\text { (プロセス管理-進渉状況共有) } \\
\text { (プロセス管理-仕様決定共有) } \\
\text { (プロセス管理-顧客対応共有) }\end{array}$ & 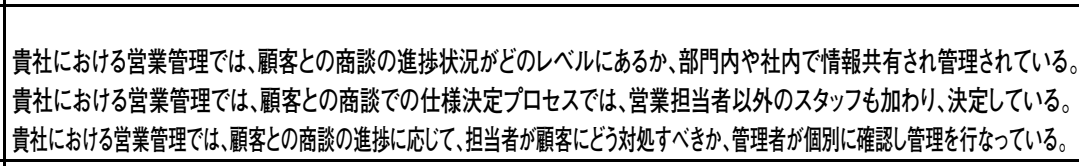 \\
\hline $\begin{array}{l}\text { 行動量管理 } \\
\text { (行動量管理-訲問回数) } \\
\text { (行動量管理-顧客面談数) } \\
\text { (行動量管理-引合件数) }\end{array}$ & 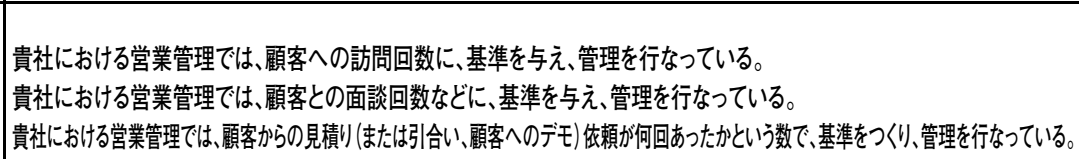 \\
\hline
\end{tabular}


表— 2

営業管理様式の選択要因に関する分析結果

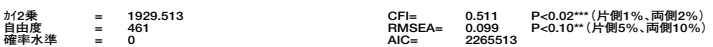

\begin{tabular}{|c|c|c|c|c|c|c|c|c|c|c|c|c|c|c|c|c|}
\hline \multirow{3}{*}{ (1) } & \multirow[b]{2}{*}{ 傮諟 $1-1$} & & \multirow{2}{*}{ 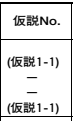 } & \multicolumn{5}{|c|}{ 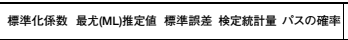 } & \multirow{2}{*}{ 有意性 } & \multirow{2}{*}{ 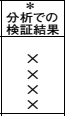 } & \multirow[t]{2}{*}{ 結㖮 1} & \multirow[t]{2}{*}{ 結龢 2} & \multirow[t]{2}{*}{ 結筒 3} & \multirow[t]{2}{*}{ 䑩龢 4} & \\
\hline & & 在㡹型(投機的) $\rightarrow$ & 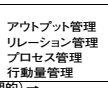 & & $\begin{array}{l}0.055 \\
0.042 \\
-0.06 \\
0.062 \\
\end{array}$ & $\begin{array}{l}0.016 \\
0.013 \\
-0.02 \\
0.023\end{array}$ & $\begin{array}{l}0.018 \\
0.016 \\
0.021 \\
0.019 \\
\end{array}$ & $\begin{array}{l}0.891 \\
0.085 \\
-0.095 \\
1.213 \\
1.213\end{array}$ & 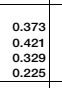 & & & & & & & \\
\hline & 㤦説 $1-2$ & 勿- & 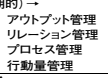 & (仮證1-2) & $\begin{array}{l}-0.038 \\
0.014 \\
0.068 \\
-0.036\end{array}$ & $\begin{array}{l}-0.012 \\
0.005 \\
0.023 \\
-0.014\end{array}$ & $\begin{array}{r}0.019 \\
0.016 \\
0.021 \\
0.02 \\
\end{array}$ & $\begin{aligned}-0.621 \\
0.279 \\
1.099 \\
-0.0704 \\
\end{aligned}$ & \begin{tabular}{r|r}
0.534 \\
0.78 \\
0.272 \\
0.481 \\
0.48
\end{tabular} & & $\begin{array}{l}x \\
x \\
x \\
x \\
\end{array}$ & & & & & \\
\hline (2) & 便説 $2-1$ & 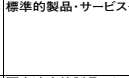 & 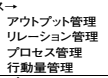 & 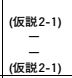 & $\begin{array}{l}0.131 \\
-0.016 \\
-0.063 \\
-0.028 \\
\end{array}$ & $\begin{array}{l}0.041 \\
-0.005 \\
-0.022 \\
-0.011\end{array}$ & $\begin{array}{r}0.02 \\
0.017 \\
0.022 \\
0.02\end{array}$ & $\begin{array}{l}2.056 \\
-0.0303 \\
-0.021 \\
-0.546 \\
-0.546\end{array}$ & $\begin{array}{l}0.04 * \\
0.762 \\
0.307 \\
0.585\end{array}$ & & $\begin{array}{l}0 \\
x \\
x \\
x \\
\end{array}$ & $\circ$ & & & & \\
\hline & 仮説 $2-2$ & 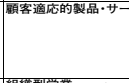 & 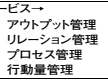 & 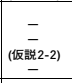 & $\begin{array}{l}0.198 \\
-0.061 \\
-0.15 \\
-0.126 \\
\end{array}$ & $\begin{aligned} 0.069 \\
-0.022 \\
-0.06 \\
-0.056\end{aligned}$ & $\begin{array}{l}0.024 \\
0.019 \\
0.025 \\
0.023 \\
\end{array}$ & $\begin{array}{l}2.942 \\
-2.163 \\
2.398 \\
-2.449 \\
\end{array}$ & $\begin{array}{l}0.003 . . \\
0.245 \\
0.016 . * \\
0.014 * .\end{array}$ & & $\begin{array}{l}0 \\
\times \\
0 \\
0\end{array}$ & & o & & & \\
\hline (3) & 便説 $3-1$ & 組㱍型営業 $\rightarrow$ & 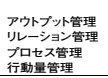 & $\begin{array}{c}- \\
\text { (仮説3-1) } \\
-\end{array}$ & $\begin{array}{l}0.001 \\
0.116 \\
0.194 \\
0.057\end{array}$ & $\begin{array}{r}0 \\
0.059 \\
0.11 \\
0.036\end{array}$ & $\begin{array}{l}0.03 \\
0.027 \\
0.036 \\
0.032\end{array}$ & $\begin{array}{r}0.009 \\
2.2 \\
3.06 \\
1.129\end{array}$ & $\begin{array}{l}0.993 \\
0.028 . * \\
0.002 \\
0.259\end{array}$ & & $\begin{array}{l}x \\
\dot{0} \\
0 \\
\dot{0} \\
x\end{array}$ & & & $\stackrel{\circ}{\circ}$ & & \\
\hline & 仮説 $3-2$ & 個人型営業 & 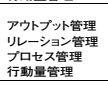 & 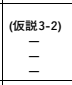 & $\begin{array}{l}0.04 \\
0.031 \\
-0.2 \\
0.098\end{array}$ & $\begin{array}{l}0.016 \\
0.013 \\
-0.09 \\
0.049\end{array}$ & $\begin{array}{l}0.024 \\
0.021 \\
0.029 \\
0.026\end{array}$ & $\begin{array}{r}0.657 \\
0.596 \\
-3.142 \\
1.91 \\
\end{array}$ & $\begin{array}{l}0.2051 \\
0.511 \\
0.551 \\
0.0022 . * \\
0.056 *\end{array}$ & & $\begin{array}{l}x \\
x \\
:\end{array}$ & & & & & \\
\hline (4) & 仮誤 $4-1$ & 差佯化 & 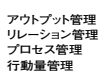 & $\begin{array}{c}- \\
\text { (仮説4-1) } \\
-\end{array}$ & $\begin{array}{l}0.086 \\
-0.07 \\
0.084 \\
0.129\end{array}$ & $\begin{array}{l}0.046 \\
-0.039 \\
0.052 \\
0.089\end{array}$ & $\begin{array}{l}0.034 \\
0.029 \\
0.028 \\
0.035\end{array}$ & $\begin{array}{r}1.38 \\
-1.345 \\
1.364 \\
2.503\end{array}$ & $\begin{array}{l}0.168 \\
0.179 \\
0.172 \\
0.012\end{array}$ & & $\begin{aligned} \Delta \\
\Delta \\
\Delta\end{aligned}$ & & $\Delta$ & & & \\
\hline & 仅説 $4-2$ & 同一化 & 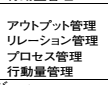 & $\begin{array}{l}\text { (仮説4-2) } \\
- \\
-\end{array}$ & $\begin{array}{l}0.133 \\
-0.041 \\
-0.029 \\
-0.003\end{array}$ & $\begin{aligned} 0.07 \\
-0.022 \\
-0.017 \\
-0.002 \\
-0.002\end{aligned}$ & $\begin{array}{l}0.033 \\
0.028 \\
0.036 \\
0.033\end{array}$ & $\begin{array}{l}2.085 \\
-0.787 \\
-0.481 \\
-0.057 \\
-0.057\end{array}$ & $\begin{array}{l}0.037 \\
0.431 \\
0.631 \\
0.954\end{array}$ & & $\begin{array}{l}0 \\
\times \\
\times \\
\times \\
\end{array}$ & 0 & & & & \\
\hline (5) & 仮説 $5-1$ & 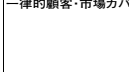 & 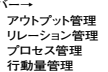 & $\begin{array}{l}\text { (扳證5-1) } \\
\text { (仮説5-1) }\end{array}$ & $\begin{array}{r}0.011 \\
0.04 \\
-0.034 \\
-0.005\end{array}$ & $\begin{array}{l}0.004 \\
\text { o.015 } \\
-0.014 \\
-0.014\end{array}$ & $\begin{array}{l}0.022 \\
0.019 \\
0.025 \\
0.023\end{array}$ & $\begin{array}{l}0.187 \\
0.776 \\
-0.553 \\
-0.104\end{array}$ & \begin{tabular}{l|l|}
0.852 & \\
0.438 \\
0.58 \\
0.917
\end{tabular} & & $\begin{array}{l}x \\
x \\
x \\
x\end{array}$ & & & & & \\
\hline & 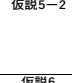 & 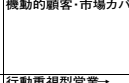 & 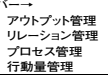 & $\begin{array}{l}- \\
\text { (仮譔5-2) } \\
\end{array}$ & $\begin{array}{l}0.158 \\
0.226 \\
0.104 \\
0.133\end{array}$ & $\begin{array}{l}0.068 \\
0.1 \\
0.051 \\
0.073\end{array}$ & $\begin{array}{l}0.028 \\
0.024 \\
0.03 \\
0.028\end{array}$ & $\begin{array}{l}2.436 \\
4.114 \\
1.683 \\
2.571 \\
2\end{array}$ & $\begin{array}{c}0.015 .: \\
0 \\
0.092 . * \\
0.091 . \\
0.01\end{array}$ & & $\begin{array}{l}\circ \\
\stackrel{0}{0} \\
0 \\
0 \\
0\end{array}$ & & & & $\begin{array}{l}0 \\
\vdots \\
8 \\
0 \\
0 \\
\end{array}$ & \\
\hline (6) & 仅潑6 & 行䡃重覞型官棠 & 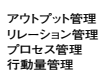 & $\begin{array}{l}\text { (仮辇6) } \\
\text { (仮謨6) }\end{array}$ & $\begin{array}{l}0.174 \\
-0.0 .08 \\
-0.03 \\
0.033\end{array}$ & $\begin{array}{l}0.073 \\
-0.025 \\
-0.014 \\
-0.092\end{array}$ & $\begin{array}{l}0.028 \\
0.022 \\
0.029 \\
0.028\end{array}$ & 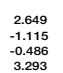 & $\begin{array}{c}0.008 . . . \\
0.265 \\
0.627 \\
0.1 . *\end{array}$ & & 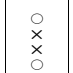 & o & & & & \\
\hline (7) & 仮説 7 & 適応奉仕型営業・ & 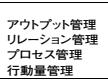 & 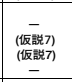 & $\begin{array}{l}0.086 \\
0.144 \\
0.033 \\
0.036\end{array}$ & $\begin{array}{l}0.042 \\
0.073 \\
0.018 \\
0.022\end{array}$ & $\begin{array}{l}0.031 \\
0.027 \\
0.034 \\
0.032\end{array}$ & $\begin{array}{l}\begin{array}{l}1.379 \\
2.776 \\
0.533 \\
0.709\end{array} \\
0.75\end{array}$ & $\begin{array}{l}0.168 \\
0.007 \\
0.594 \\
0.478\end{array}$ & & $\begin{array}{l}\Delta \\
\dot{x} \\
\dot{x} \\
x\end{array}$ & & $\circ$ & & & \\
\hline (8) & 仮敦8 & 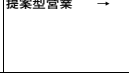 & 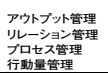 & 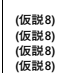 & $\begin{array}{c}0.168 \\
0.274 \\
0.348 \\
0.15\end{array}$ & $\begin{array}{l}0.084 \\
0.14 \\
0.197 \\
0.094\end{array}$ & $\begin{array}{l}0.033 \\
\text { o. } \begin{array}{l}0.29 \\
0.038 \\
0.033\end{array}\end{array}$ & $\begin{aligned} 2.563 \\
4.668 \\
5.119 \\
2.88\end{aligned}$ & $\begin{array}{r}0.01 \\
0 . \\
0 . \\
0.004 .\end{array}$ & & $\begin{array}{l}\circ \\
: \\
\circ \\
0 \\
0\end{array}$ & & & & $\begin{array}{l}0 \\
8 \\
0 \\
0 \\
0\end{array}$ & \\
\hline (9) & 仮説9 & ワークシシツフ型営業ー & 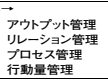 & 㤆镜9) & $\begin{array}{l}-0.037 \\
0.0148 \\
0.221 \\
-0.018\end{array}$ & $\begin{aligned}-0.017 \\
0.07 \\
0.115 \\
-0.01\end{aligned}$ & $\begin{array}{l}0.028 \\
0.025 \\
0.033 \\
0.029\end{array}$ & $\begin{array}{l}-0.613 \\
2.785 \\
3.457 \\
-0.356\end{array}$ & $\begin{array}{c}0.54 \\
0.005 \\
0 \\
0.722\end{array}$ & & $\begin{array}{l}x \\
0 \\
0 \\
0 \\
x \\
x\end{array}$ & & $\begin{array}{l}\circ \\
\circ\end{array}$ & & & \\
\hline 10 & 作諟 $10-1$ & 新梘顛客開拓 $\rightarrow$ & 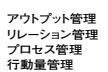 & 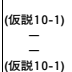 & $\begin{array}{l}0.254 \\
0.198 \\
0.13 \\
0.102\end{array}$ & $\begin{array}{l}0.123 \\
0.098 \\
0.071 \\
0.062\end{array}$ & $\begin{array}{l}0.034 \\
0.027 \\
0.034 \\
0.031\end{array}$ & $\begin{array}{l}3.571 \\
3.649 \\
2.088 \\
1.987\end{array}$ & $\begin{aligned} 0 \\
0 \\
0.037 . \\
0.037 \\
0.047\end{aligned}$ & & $\begin{array}{l}\circ \\
: \\
\vdots \\
0\end{array}$ & & & & $\begin{array}{l}0 \\
8 \\
0 \\
0 \\
0\end{array}$ & \\
\hline & 依梳 $10-2$ & 既存領客維持 $\rightarrow$ & 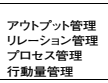 & $\begin{array}{c}\text { (1反 弪 } 10-2) \\
- \\
-\end{array}$ & $\begin{array}{l}0.217 \\
0.164 \\
0.06 \\
0.157\end{array}$ & $\begin{array}{l}0.114 \\
0.088 \\
0.036 \\
0.105\end{array}$ & $\begin{array}{l}0.036 \\
0.029 \\
0.037 \\
0.035\end{array}$ & $\begin{array}{l}3.16 \\
3.064 \\
0.969 \\
3.006\end{array}$ & $\begin{array}{l}0.002 . \\
0.002 . \\
0.332 \\
0.003 .\end{array}$ & & $\begin{array}{l}0 \\
\vdots \\
x \\
\times \\
0 \\
\end{array}$ & & & & & \\
\hline (11) & 作搃11-1 & 長·营業サイクル & 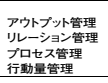 & 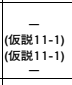 & $\begin{array}{l}-0.228 \\
-0.157 \\
0.084 \\
0.051\end{array}$ & $\begin{aligned}-0.072 \\
-0.051 \\
0.03 \\
0.02 \\
\end{aligned}$ & $\begin{array}{l}0.022 \\
0.017 \\
0.022 \\
0.02 \\
0.02\end{array}$ & $\begin{array}{r}-3.294 \\
-2.2943 \\
1.369 \\
1 \\
\end{array}$ & $\begin{array}{l}0 \\
0 .: 1 \\
0.073 \\
0.171 \\
0.317\end{array}$ & & $\begin{array}{l}: \\
\dot{\hat{x}} \\
\end{array}$ & & & $\Delta$ & & \\
\hline & 作説11-2 & 短・常羣サイクルー & 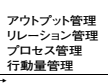 & 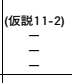 & $\begin{aligned}-0.048 \\
0.067 \\
0.065 \\
-0.027\end{aligned}$ & $\begin{aligned}-0.014 \\
0.02 \\
0.021 \\
-0.01 \\
\end{aligned}$ & $\begin{array}{r}0.018 \\
0.015 \\
0.02 \\
0.018 \\
\end{array}$ & $\begin{array}{r}-0.78 \\
1.287 \\
1.055 \\
-0.539 \\
\end{array}$ & $\begin{array}{c}0.435 \\
0.198 \\
0.292 \\
0.59 \\
\end{array}$ & & $\begin{array}{l}x \\
\vec{a} \\
x \\
x \\
x\end{array}$ & & & & & \\
\hline (1) & 仮謨12 12 & & 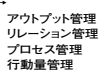 & $\begin{array}{l}- \\
\text { (仮联12) } \\
-\end{array}$ & $\begin{array}{l}0.043 \\
0.024 \\
-0.009 \\
-0.025\end{array}$ & $\begin{array}{l}0.009 \\
0.005 \\
-0.021 \\
-0.007\end{array}$ & $\begin{array}{l}0.013 \\
0.011 \\
0.015 \\
0.014\end{array}$ & $\begin{array}{l}0.703 \\
0.465 \\
-x_{-1438} \\
-0.503\end{array}$ & $\begin{array}{l}0.482 \\
0.642 \\
0.151 \\
0.615\end{array}$ & & $\begin{array}{l}x \\
x \\
\hat{x}\end{array}$ & & & & & \\
\hline (13) & 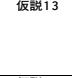 & 不碓英性の高ざ & 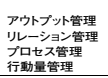 & 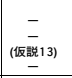 & $\begin{array}{l}-0.005 \\
-0.0 .037 \\
0.103 \\
0.095\end{array}$ & $\begin{array}{l}-0.001 \\
-0.009 \\
0.026 \\
0.027\end{array}$ & $\begin{array}{l}0.014 \\
0.012 \\
0.016 \\
0.015\end{array}$ & $\begin{array}{l}-0.079 \\
-0.0722 \\
-.667 \\
1.864\end{array}$ & $\begin{array}{l}0.937 \\
0.47 \\
0.095 \\
0.062 .\end{array}$ & & $\begin{array}{l}x \\
x \\
x \\
0 \\
0 \\
0\end{array}$ & & & $\circ$ & & 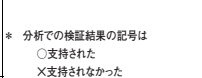 \\
\hline (1) & 仮説 14 & 市埸变化の速ざ & 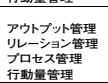 & 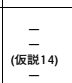 & $\begin{array}{r}-0.117 \\
-0.042 \\
0.073 \\
-0.043\end{array}$ & $\begin{aligned}-0.026 \\
-0.01 \\
0.018 \\
-0.012\end{aligned}$ & $\begin{array}{l}0.014 \\
0.012 \\
0.015 \\
0.014\end{array}$ & $\begin{array}{l}-1.852 \\
-0.017 \\
-1.187 \\
-0.851\end{array}$ & $\begin{array}{ll}0.004 \\
0.064 \\
0.414 \\
0.235 \\
0.395\end{array}$ & & $\begin{array}{l}\dot{x} \\
\dot{x} \\
x\end{array}$ & & & & & 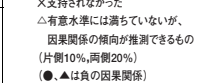 \\
\hline (15) & 仅説 15 & 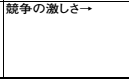 & 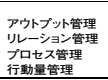 & 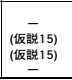 & $\begin{aligned} 0.063 \\
0.001 \\
\text { o.0.61 } \\
-0.074\end{aligned}$ & $\begin{array}{l}0.019 \\
0.028 \\
0.023 \\
-0.028 \\
\end{array}$ & $\begin{array}{l}0.019 \\
0.016 \\
0.021 \\
0.019\end{array}$ & $\begin{array}{r}1.031 \\
1.738 \\
1.075 \\
-1.457 \\
\end{array}$ & $\begin{array}{l}\begin{array}{l}0.302 \\
0.02 \\
0.283 \\
0.283 \\
0.145\end{array} \\
\end{array}$ & & $\begin{array}{l}x \\
\dot{x} \\
\times \\
x \\
\Delta\end{array}$ & & & 0 & & 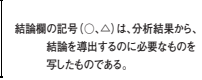 \\
\hline
\end{tabular}


口図- 5

検証方法の概念図

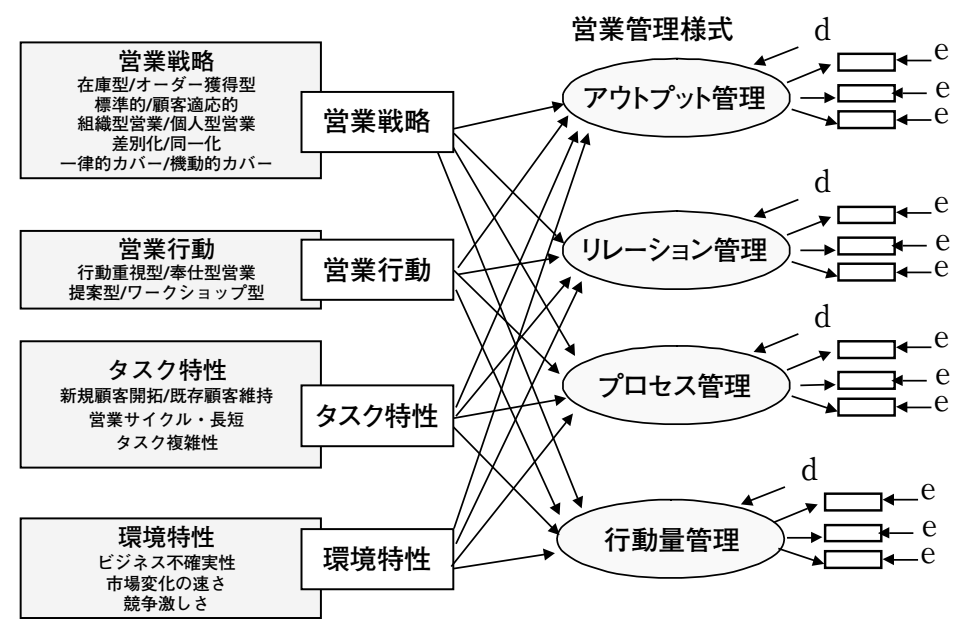

(同一化 $\rightarrow$ アウトプット管理) は支持されてお り，仮説 4-1 (差別化 $\rightarrow$ プロセス管理）は 支持されなかったが，因果関係が推測できる ものとなっている。従って全体としての仮説 4 は概ね支持されたといえる。

仮説 5 の検証結果は(5)である。仮説 5-1 (一律的な顧客・市場カバーーアウトプット管 理，行動量管理）は，アウトプット管理と符 号が整合的であることが観察できるにとどま っている。他方，仮説 5-2（機動的な顧客. 市場カバーープロセス管理）は支持されたが, さらに，アウトプット管理，リレーション管 理，行動量管理とも，因果関係が確認できる ものとなっている。このような検証結果から， 全体としての仮説 5 の機動的/一律的という対 比での管理方式選択の差異は支持されなかっ た。なお，機動的顧客・市場カバーでは，管 理方式の種類に関係なく，管理がほぼ全般的 に，用いられていることが発見的事実として 確認できる。

仮説 6 の検証結果は (6)である。行動重視型 営業が指向される場合には，アウトプット管 理，行動量管理が選択されることが確認でき, 支持された。

仮説 7 の検証結果は(7)である。適応奉仕型 営業が指向される場合には,リレーション管 理が選択されることが確認でき, 部分的に支 持された。

仮説 8 の検証結果は (8)である。提案型営業 が指向される場合には，プロセス管理，リレ ーション管理, アウトプット管理, 行動量管 理のそれぞれが用いられることが確認でき, 支持された。つまり，提案型営業では，仮説 に設定したとおり，管理方式の種類に関係な く，ほぼ全般的に管理が用いられていること がわかる。

仮説 9 の検証結果は9である。ワークショ 
ップ型営業が指向される場合には，プロセス 管理が選択され，支持された。また，リレー ション管理も用いられることが確認できる。

\section{（2）タスク特性/環境特性と営業管理様式の選択}

仮説 10 の検証結果は10である。仮説 $10-$

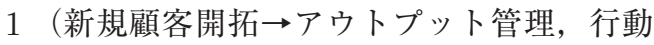

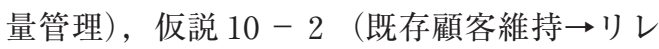
ーション管理）の双方とも支持された。しか し検証結果を見ると新規顧客開拓と既存顧客 維持で管理方式の選択が異なるという，全体 としての仮説 10 は支持されなかった。また新 規顧客開拓においては，いずれの場合も管理 方式がほぼ全般的に用いられる傾向にあるこ とが確認できる。

仮説 11 の検証結果は111である。仮説 $11-$

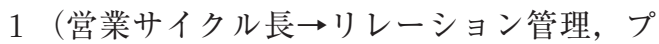
ロセス管理), 仮説 $11-2$ (営業サイクル短 ーアウトプット管理）は，ともに支持されな かった。しかし，営業サイクルが長い場合に は，プロセス管理との正の因果関係が推測で き，また，アウトプット管理，リレーション 管理との間に, 強い負の因果関係があるため, 仮説に沿った因果関係の存在を推測すること ができよう。

仮説 12 の検証結果は12)である。仮説は支持 されず，プロセス管理とは負の因果関係が推 測できる。

仮説 13 の検証結果は13)である。ビジネス不 確実性が増す場合は，プロセス管理が用いら れることが確認でき，支持された。ただし， 行動量管理も用いられていることが確認でき
る。

仮説 14 の検証結果は14)であり，仮説は支持 されなかった。なお，アウトプット管理と負 の因果関係があることは，間接的に仮説に沿 った因果関係の存在を示唆するものといえる。

仮説 15 の検証結果は15である。競争の激し さが増すにつれて,リレーション管理が強め に用いられることが確認でき，部分的に支持 されたといえる。

\section{3. 検証結果から得られる結論}

\section{（1）標準的な営業戦略·営業行動と管理方式 の選択}

仮説 2-1 (標準的・製品サービス)，42 (同一化), 6 (行動重視型営業) の検証に より，標準的な営業戦略，営業行動が指向さ れる場合には，アウトプット管理や，行動量 管理が用いられる傾向にあることがわかる。 このようなことから以下のような結論が得ら れよう。

結論 1 . 標準的な営業戦略, 営業行動が指向 される場合には，アウトプット管理 や行動量管理の実践度が高まる。

\section{（2）顧客適応的な営業戦略·営業行動と管理 方式の選択}

仮説 7 (適応奉仕型営業), 9（ワークショ ップ型営業）の検証により, 顧客適応的な営 業行動が指向される場合には, リレーション 管理やプロセス管理が用いられる傾向にある ことがわかる。また，仮説 $2-2$ (顧客適応 的·製品サービス）では，リレーション管理と 
の因果関係は確認できないものの，プロセス 管理が用いられる傾向にあることがわかる。 そして，仮説 4-1 (差別化) は支持されて いないが，その傾向を推測できるものとなっ ている。このようなことから以下のような結 論が得られよう。

結論 2. 顧客適応的な営業戦略, 営業行動が 指向される場合には, リレーション 管理や，プロセス管理の実践度が高 まる。

（3）タスク特性, 環境特性, 意思決定・責任 の所在と管理方式の選択

仮説 13 (ビジネス不確実性), 仮説 15（競 争の激しさ）の検証により，ビジネス不確実 性の高い場合や，競争の激しさが高い場合に は，リレーション管理やプロセス管理が用い られることがわかる。また，仮説 $11-1$ （長・営業サイクル）は支持されていないが, プロセス管理が用いられる傾向が推測できる ものとなっている。そして, 仮説 3 (組織型 営業）の検証により, 組織的な営業活動が目 指される場合には，プロセス管理やリレーシ ヨン管理が用いられることがわかる。よって 以下のような結論が得られよう。

結論 3. 競争の激しい場合や, 環境不確定性 が高い場合，そして組織的な対応が 必要な場合には, リレーション管理 やプロセス管理の実践度が高まる。

以上は，仮説提示の冒頭に示した仮説導出 の前提に関連するものであるが，それ以外の 発見的結論も見出されたので，それを提示し
よう。

\section{（4）機動的顧客·市場カバー, 提案型営業, 新規顧客開拓が指向される場合と管理方 式の選択}

仮説 5-2（機動的顧客·市場カバー）８ (提案型営業), $10-1$ (新規顧客開拓), の 検証結果は，あらゆる営業管理の管理方式が 用いられる可能性を示している。これは従来 の理論だけでは論理的な説明はつきにくくも 考えられるが，実務における視点からみれば， いづれも積極的な営業活動が展開される場合 であろうと考えられる。また，これらの分析 結果は, 従来の研究がそうであったように, 成果主義的か行動主義的かというような二元 対比, 二者択一的な方法で, 営業部門の管理 を分析しようとすることの不充分さを示唆す ることも確かであろう。

従ってこれを結論とすることはやや課題も 残るが, 今後の検討が特に必要という意味で 発見的結論として掲げておきたい。

結論 4. 機動的・顧客市場カバーや，提案型営 業, 新規顧客開拓などの積極的な営 業展開が指向される場合には，営業 管理の管理方式が，その種類に関係 なく，全般的に用いられる傾向にあ る。

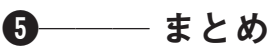

\section{1. 本研究における研究に向けての示唆}

本研究で明らかになったことは, 指向され る営業戦略や営業行動，またタスク特性や環 境特性によっても, 営業部門の管理が変化し, 
それには法則性がみられるということである。

つまり, 研究への示唆として提示できるこ とは, 先行研究で営業管理様式の選択を決め るものとされてきた，「成果を正しく評価する 能力」と「達成までのプロセスの明白性」の 二要因とは別の視点からも, 営業管理様式の 選択の分析が可能であるということである。 よって以下のような示唆が得られよう。

\section{本研究での示唆 1.}

営業管理様式の選択について分析 を行なう場合には，「成果を正しく 評価する能力」と「達成までのプ ロセスの明白性」という二要因か らのみでなく, 戦略·行動・夕スク・ 環境等のような，より多角的な視 点から分析を行なう必要がある。

本研究での分析をまとめると, 営業戦略・ 営業行動で，標準的なものが指向される場合 には，アウトプット管理や行動量管理が選択 され（結論 1), また, 顧客適応的な営業戦 略・営業行動が指向される場合は, プロセス 管理やリレーション管理が選択される（結論 2）ことが確認された。また，営業タスクの複 雑性が増す場合や，環境不確定性が増す場合 にも，プロセス管理の遂行度が高まることが 確認された（結論 3 )。

そして，機動的な顧客・市場カバー，提案型 営業, 新規顧客開拓などの積極的な営業活動 を展開する場合には，管理方式がその種類を 問わず，全般的に用いられることも導き出さ れた（結論 4)。

特にこの 4 つめの結論から得られる示唆は, 先行研究で行なわれてきた, 成果主義的か,
行動主義的かといった二元対比で，なおかつ 二者択一的な方法で，営業管理様式を分析す るのには限界があるのでないかということで ある。つまり，本研究における二つめの示唆 として，以下のことが得られよう。

本研究での示唆 2 .

営業管理様式を分析するにあたっ て，成果主義的（アウトプット管 理）か，行動主義的（プロセス管 理）かという, 従来の二元対比で, なおかつ二者択一的な方法によっ て分析を行なうのには限界がある。

\section{2. 本研究での実務に向けた示唆}

本研究の検証結果は, いうまでもなく, 調 査への回答を行なった各企業の営業活動の経 験蓄積が，デー夕解析にあらわれてきたもの である。しかし，個々の企業や営業部門では, 自社の営業管理がどのような理由で選択され たかについて，明確には認識していないこと が多いのでないだろうか。実務で遂行される 営業管理様式は，管理者自身が意識するしな いは別として，過去の成功体験や失敗体験の 蓄積の中から導き出されたものが多いといえ よう。そしてもちろん，これらは重視される 必要もあろう。

しかし, 企業や営業部門を取り巻く環境が 継続的に変化し, その変化の速さが増す状況 の中では, 営業管理も継続的に変化させ, 適 応させていかなくてはならず, 過去の経験の みに頼って, 営業管理様式を決めてしまうこ とは, 環境変化に適応できない要因を, 自ら に内在させてしまいかねないのではないだろ うか。つまり, 営業管理様式は, 営業戦略や 
営業行動, タスクや環境が変化すれば, それ を常に変えていく必要があるのでないだろう か。このようなことから以下のような示唆が 得られよう。

\section{本研究での示唆 3.}

実務における営業管理選択は，蓄 積された経験からのみでなく，営 業戦略, 営業行動, 夕スク特性, 環境特性の変化に合わせて, 適確 に選択を行ない，さらに与件の変 化に応じて，それを修正していく 必要がある。

自社・自部門の営業部門の営業管理は，何故 どのような理由で行われてきているのか。ま た，営業戦略や営業行動, 営業夕スクを変更 した場合や，環境変化が起きた場合に，その 営業管理をどのように見直すべきなのか。本 研究での検証結果は，実務に向けても営業部 門の管理のあり方について，今一度，みつめ 直す必要があることを提起しているのではな いだろうか。

\section{3. 本研究の限界と今後の課題}

本研究は，これまで先行研究で提示されて いる営業活動での戦略や行動を参考にしなが ら，営業部門の施策に置き換え，さらにタス ク特性や環境特性を織り达んで，営業管理様 式の選択について分析を行なったものである。

しかし，営業管理様式の選択に焦点をあて ているが，成果までを含めて，その因果関係 を包括的に分析しょうとしたものではない。 営業戦略, 営業行動, 夕スク特性, 環境特性 という与件により，営業管理の管理方式がど
のように用いられ，さらに営業成果がどう高 まるかという，複合的な因果関係については 分析を行なえていない。また，先行研究で提 示された戦略や行動, タスク, 環境の概念も, 分析フレームや調査に全て落とし込めたわけ ではない。さらに，本研究で取り上げた，営 業戦略, 営業行動, 夕スク特性, 環境特性と いう4つの要因の間にも，何らかの因果関係 があるはずであるが，本研究では捨象してし まっている。これらについては，今後，新た な分析フレームの設定や，さらなるデータ収 集を通しての検証・分析が必要であると考え られる。

営業活動や営業管理に関する実証研究は, まだ数も少ないため，様々な与件を取り入れ ながら, 分析フレームを構築しての研究の蓄 積が，今後も引き続き必要と考えられる。

注

1）Eisenhardt（1985）が提示した，取引コスト分析 や認知的評価論を用いると, 取引コスト分析では, 「コスト」と「ベネフィット」の最適化の中で，ま た，認知的評価論では，「管理と評価のフィードバ ック」と「動機付けのあり方」で，営業管理様式 選択の分析がなされることになる。Eisenhardt

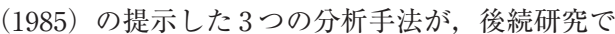
引用されない理由として, エージェンシー理論と 取引コスト分析は，組織文化を折り达んだり，営 業部門での具体的な管理施策と結びつける点で弱 いからであると考えられ，また，認知的評価論は， 人事管理的な視点で，管理と効用の関係を分析す るには優れていながらも, やはり, 営業戦略や環 境の変化, 組織文化を折り込むことに弱いからで あると考えられる。

2) Jaworski (1988) では，環境的要因（Environment） として, マクロ的要因や, 競争的要因, 内的要因 の三つがあげられており，また，Jaworski et al. （1993）では，先行要因として，マーケティング部 門の特徴と夕スク複雑性の二つがあげられている。 本研究で構築される分析フレームの構成要素の一 部は，この Jaworski (1988), Jaworski et al. 
（1993）の分析フレームの援用を受けて，その一部 を取り达み，営業部門で指向される具体的施策や 具体的要因と結びつけながら, 実証的な検証を目 的とする分析フレームに組み达んだものといえる。

3）清宮（2004b）では，営業プロセスにあわせて行な われる管理方式の分類を 6 つに分け提示している が，本研究ではそれらのうち，図4で示されてい る, アウトプット管理, リレーション管理, プロ セス管理, 行動量管理の 4 つの管理方式を取り上 げている。なお，これら 4 つの管理方式を展開し た後に，それを補完する二次的な対応として行な われる, 管理方式のビュー・修正, 報奨の 2 つは, 本研究での分析から除外している。

4）調査対象は日本企業 1998 社で，各企業の営業管理 者およびマーケティング担当者への郵送による送 付・回収にて行なった。回答企業は 357 社であっ たが，解析対象とする回答に欠損のある企業を解 析から除外したため, 有効回答数は 324 社（回答 率 $16.2 \%$ ）となっている。なお，使用しているデー 夕は，清宮（2004a, 2004b）で検証に使用したデー 夕と同じ調査で得られたものである。

\section{参考文献}

Anderson, Erin \& Oliver, Richard ( 1987) "Perspectives on Behavior-Based Versus Outcome-Based Salesforce Control Systems, " Journal of Marketing, Vol51 OCT, pp76 88.

Alderson,W. (1957) Marketing Behavior and Excutive Action, Richard D. Irwin. (石原武政他訳『マ ーケティング行動と経営者行為』千倉書房, 1984)

Bucklin, L.P. (1965) "Postponement, Speculation and the Structure of Distribution Channels, " Journal of Marketing Reserch, Vol. 2No. 3, pp263-274.

Challagalla, Goutam N. \& Shervani, Tasadduq A (1997) "A Measurement Model of the Dimensions and Types of Output and Behavior Control: An Empircal Test in a Salesforce Context, "Journal of Business Research, 39, pp159-172.

Cravens, David W., Ingram, Thomas N., LaForge, Raymond W. \& Young, Clifford E. ( 1993) "Behavior-Based and Outcome-based Salesforce Control System, "Journal of Marketing, Vol. 57, pp47-59.

Eisenhardt,Kathleen M. (1985) "Control:Organizational and Economic Approaches, "Management Science, Vol. 31, pp134-149.

細井謙一（2000）「営業活動の日本的特徵」高嶋克義 編『日本型マーケティング』千倉書房, pp137-152.
石井淳蔵（1993）『マーケティングの神話』日本経済 新聞社.

石井淳蔵（1998）「流通と営業のシステム革新」マー ケティング革新の時代『営業・流通革新』有斐閣, pp1-28.

Jaworski, Bernard.J (1988) "Toward a Theory of Marketing Control:Environmental Context, Control Types,and Consequences, "Journal of Marketing, Vol. 52, July, pp23 39.

Jaworski „Bernard. J., Stathakopoilos, Vlasis., Krishnan, Shanker, H. ( 1993) "Control Conbination in Marketing:Conceptual Framework and Empirical Evidence, "Journal of Marketing, Vol. 57, January, pp57 $\sim 69$.

金顕哲（1995）「営業の関係理論」石井淳蔵・嶋口 充輝編『営業の本質』有斐閣, pp191-217.

Ouchi, William G. (1979) "A Conceptual Framework For The Design of Organizational Control Mechanisms, "Management Science, Vol25, No9, pp833-848.

Oliver, Richard L. \& Anderson, Erin (1994) "An Empirical Test of the Consequences of Behaviorand Outcome-Based Sales Control Systems, " Journal of Marketing, 58, October, pp53-67.

Porter,M.E. (1980) COMPETITIVE STRATEGY (土岐伸訳『新訂・競争の戦略』ダイヤモンド 社,1982)

Porter,M.E. (1985) COMPETITIVE ADVANTAGE (土岐伸訳『競争優位の戦略』ダイヤモンド 社,1985)

清宮政宏（2004 a ）「営業活動で指向される戦略·行動 とその成果に関する一考察」『マーケティングジ ヤーナル』No93, pp56-72

清宮政宏（2004 b ）「営業管理様式と営業成果の因果 関係に関する研究」『流通研究』Vol. 7, No. 2, pp91-112.

嶋口充輝（1986）『統合マーケティング』日本経済新 聞社.

嶋口充輝（1995）「ワークショップ型営業の可能性 関係性時代の営業力強化を求めて」石井淳蔵・嶋 口充輝編『営業の本質』有斐閣, pp290-316.

嶋口充輝（1997）『柔らかいマーケティングの論理』 ダイヤモンド社.

Slater,Stanley F \& M.Olson,Eric M (2000) "Strategy Type and Performance:The Influence of Sales force Management,"Strategy Management Journal, 21, pp813-829.

高嶋克義（1995）「営業の戦略と組織」石井淳蔵・嶋 
口充輝編『営業の本質』有斐閣, pp260-289.

高嶋克義（1998）『生産財の取引戦略一顧客適応と標 準化-』千倉書房.

高嶋克義（2000a）「日本企業における営業管理様式の

選択」高嶋克義編『日本型マーケティング』千倉

書房, pp153-172.

高嶋克義（2000b）「営業管理様式の選択に関する新視

点」『流通研究』, pp $1 \sim 16$.

田村正紀 (1999)『機動営業力』日本経済新聞社.

田中由多加（1986）『セリング・エッセンス』創成社.

金 顕哲（きむひゅんちゅる）

ソウル大学国際大学院準教授

清宮 政宏（せいみやまさひろ）

筑波大学大学院ビジネス科学研究科博士課程修了

博士 (経営学) 